\title{
Effects of Alligator Pepper (Aframomum Melegueta) Meal Additive Diets on Haematological Indices of Clarias Gariepinus (Burchell, 1822)
}

\author{
Kwankwa, T, Sogbesan, O.A.* \\ Department of Fisheries, Modibbo Adama University of Technology, Yola \\ *Corresponding Author: Sogbesan, O.A, Department of Fisheries, Modibbo Adama University of \\ Technology, Yola.
}

\begin{abstract}
The need to boost fish immunity and enhance their growth was a key tool in aquaculture development. A semi-flow through system was used to conduct the performance of Clarias gariepinus fingerlings fed Alligator Pepper (Aframomum Melegueta) meal additive diets. Three Hundred (300) Clarias gariepinus fingerlings of mean weight, $3.2+0.11 \mathrm{~g}$ and length $7.30+0.80 \mathrm{~cm}$ were acclimatized and stocked at Twenty (20) fingerlings per tanks._. All diet prepared were $40.00 \%$ crude protein. Different levels Of alligator pepper were included at T1 0.00\%, T2 1.50\%, T3 3.00\%, T4 4.50\% and T5 $6.00 \%$ and fed for 12 weeks. At the end of the experiment, blood samples were collected and analysed in the laboratory. Data generated were analyzed using ANOVA. The result of the experiment showed that T5 had the highest white blood cell with 600C/L while T1 the lowest with 400C/L and T1 had the highest packed cell volume and haemoglobin concentration, while T5 had the lowest PVC and HB. Based on the results from these findings, Alligator pepper meal additive diet is recommended at a range of $3.0-6.0 \mathrm{~g} / 100 \mathrm{~g}$ of diet for sustainable fish production
\end{abstract}

Keywords: Alligator pepper, haematology, additive, Clarias gariepinus.

\section{INTRODUCTION}

Fish cultures are at risk due to the adverse effects of stress. Blood chemistry and haematological measurements can provide valuable physiological indices that may offer critical feedback on different stressors. Haematological characteristics of most fish have been studied with the aim to establish normal value range and any deviation from it may indicate a disturbance in the physiological process (Rainzapaiva et al., 2000). Haematological properties and concentrations vary with nutritional status, health and strain of fish species as well as water parameter values and seasonality (Sogbesan and Ahmed, 2018).

According to Gabriel et al. (2007), haematological studies have been widely used as means of assessing health status of fish and the establishment of the haematological characteristics of fishes generally serves as a standard for physiological, pathological or toxicological studies. Haematological parameters of different species of fish and screening test provide useful information through which valuable and informative conclusions could be drawn (Gabriel et al., 2004). According to Ezeric (2001), the haematological and biochemical indices of farm fish which include haemoglobin, red blood cells, white blood cells, packed cell volume, plasma protein, blood glucose, specific gravity of blood plasma and whole blood, coagulation time etc. have been analyzed and have been variously reported as important tools to assess the performance, viability and health status of Akinwande et al. (2004) opined that a measurable increase in white blood count of fish or any animal is a function of immunity and animals' resistance to some vulnerable illness or disease. This increase might indicate that the fish under study had high immunity or resistance to disease. The use of haematological values as indices of diagnosing diseases and stress induced condition as well as for feed assessment is well documented (Fagbenro et al., 1993; Adeparusi and Ajayi, 2004 and Akintayo et al,. 2008). According to Osuigwe et al. (2007) the PCV, RBC count, WBC count, and HB concentration decreased significantly with increasing dietary jack bean seed meal, such that fish fed the control diet had the highest values that were significantly different from the value obtained from Clarias gariepinus fed other diets. 


\section{Materials ANd Methods}

\subsection{Experimental Location}

The experiment was carried out at Teaching and Research Fish Farm, Department of Fisheries, Modibbo Adama University of Technology, Yola. The experiment lasted for 12 weeks. The experiment was sited in Yola, Adamawa State Nigeria, inside Modibbo Adama University of Technology, Yola. Adamawa State lies between Latitudes $7^{\circ} \mathrm{N}$ and $11^{\circ} \mathrm{N}$ of the Equator and Longitude $11^{\circ} \mathrm{N}$ and $14^{\circ} \mathrm{E}$ of the Greenwich Meridian. Adamawa State has an Agro based economy with over $50 \%$ of the populace actively involved in farming either on full time or part time scale (Mishelia et al., 2000). Five experimental sets in triplicate were used for this experiment.

\subsection{Experimental Design}

A factorial design arranged in completely randomized design was used for this experiment. There were five treatments which were replicated thrice making a total of fifteen experimental units.

\subsection{Experimental Set-up}

The experimental set-up was a semi-flow through system consists of fifteen (15) tanks. Twenty fingerlings were assigned to each tanks of 40 liters filled with 30 liters of water.

\subsection{Experimental Fish}

300 fingerlings of Clarias gariepinus was purchased from Modibbo Adama University of Technology Yola, Fisheries Farm and acclimatized at Research Farm. The Clarias gariepinus fingerlings were randomly assigned to each of the fifteen tanks. And blood samples were taken after the twelve weeks experiment.

\subsection{Preparation of Powdered Samples of Fruits}

Five hundred $(500 \mathrm{~g})$ grams of alligator pepper was cleaned with water to remove foreign particles (such as stone etc.). The samples were subjected to drying process using oven-drying at $70^{\circ} \mathrm{c}$ to obtain moisture ranges between 4-6\%. The dried fruits were milled into powder using manual grinding machine (Model, Crown). The powder was further sieved using $0.45 \mu \mathrm{m}$ sieve aperture. The fine particles obtained from the fruit was packaged using poly ethylene bag for further analysis.

\subsection{Determination of Phytochemicals}

\subsubsection{Flavonoid Content}

This was determined according to the method of Harborne (1973). 5gram of the sample was boiled in $50 \mathrm{ml}$ of $2 \mathrm{M} \mathrm{HCl}$ solution for $30 \mathrm{mins}$ under reflux. It was allowed to cool and then filtered through Whatman No 42 filter paper. A measured volume of the extract was treated with equal of ethyl acetate starting with drop. The flavonoid precipitated was recovered by filtration using weighed filter paper. The resulting weight difference gave the weight of flavonoid in the sample.

\subsubsection{Tannin Content}

The method of Swain (1979) was used for the determination of tannin contents of each sample. $0.2 \mathrm{~g}$ of finely ground sample was measured into a $50 \mathrm{ml}$ beaker. $20 \mathrm{ml}$ of $50 \%$ methanol was added and covered with paraffin and placed in a water bath at $77-80^{\circ} \mathrm{c}$ for $1 \mathrm{hr}$ and stirred with a glass rod to prevent lumping. The extract was quantitatively filtered using a double layered Whatman No. 1 filter paper into a $100 \mathrm{ml}$ volumetric flask using $50 \%$ methanol to rinse. This was made up to mark with distilled water and thoroughly mixed. $1 \mathrm{ml}$ of sample extract was pipette into $50 \mathrm{ml}$ volumetric flask, $20 \mathrm{ml}$ distilled water, $2.5 \mathrm{ml}$ Folin-Denis reagent and $10 \mathrm{ml}$ of $17 \% \mathrm{Na}_{2} \mathrm{CO}_{3}$ were added and mixed properly. The mixture was made up to mark with distilled water, mixed well and allowed to stand for 20mins when a bluish-green colouration developed. Standard Tannic Acid solutions of range 0-10 ppm were treated similarly as $1 \mathrm{ml}$ of sample above. The absorbencies of the Tannic Acid Standard solutions as well as samples were read after colour development on a spetronic 21D spectrophotometer at a wavelength of $760 \mathrm{~nm}$.

Percentage tannin was calculated using the formula:

Tannin $(\%)=$ Absorbance of sample $\times$ Dilation factor ; Weight of sample $\times 10,000$ 


\subsubsection{Phytate Content}

This was done by the alkaline precipitation gravimetric method described by Harborne, (1973). The Phytic Acid (Total Phosphorus) test kit was used.

\subsubsection{Saponin Content}

The spectrophotometer method of Brunner (1984) was used for saponin analysis. 1g of finely ground sample was weighed into a $250 \mathrm{ml}$ beaker and $100 \mathrm{ml}$ isobutyl alcohol was added. The mixture was shaken on a UDY shaker for $5 \mathrm{~h}$ to ensure uniform mixing. Thereafter, the mixture was filtered through a Whatman No. 1 filter paper into a $100 \mathrm{ml}$ beaker and $20 \mathrm{ml}$ of $40 \%$ saturated solution of magnesium carbonate added. The mixture obtained with saturated $\mathrm{MgCO}_{3}$ was again filtered through a Whatman No.1 filter paper to obtain a clear colourless solution. $1 \mathrm{ml}$ of the colourless solution was pipette into $50 \mathrm{ml}$ volumetric flask and $2 \mathrm{ml}$ of $5 \% \mathrm{FeCl}_{3}$ solution was added and made up to mark with distilled water. It was allowed to stand for 30mins for blood red colour to develop. 0-10ppm standard saponin solutions were prepared from saponin stock solution. The standard solutions were treated similarly with $2 \mathrm{ml}$ of $5 \% \mathrm{FeCl}_{3}$ solution as done for $1 \mathrm{ml} 3$ above. The absorbance's of the sample as well as standard saponin solution were read after colour development. The Spectrophotometer was set at a wavelength of $380 \mathrm{~nm}$.

Percentage saponin was calculated using the formula:

Saponin $(\%)=$ absorbance of sample $\times$ Average gradient $\times$ Dilution Factor

Weight of sample $\times 10,000$

\subsubsection{Alkaloid Content}

This was done by the alkaline precipitation gravimetric method described by Harborne (1973). A measured weight of the samples was dispersed in $1 \%$ acetic acid solution in ethanol to form a ratio of 1 .

\subsubsection{Steroids}

$100 \mathrm{mg}$ of the extract was dissolved in $2 \mathrm{ml}$ of chloroform and few drops of sulphuric acid were carefully added to form a lower layer. A reddish brown colour at the interface indicates the presence of steroidal ring. The estimation was done according to Harbone (1973) method.

\subsubsection{Antraquinones}

About $0.5 \mathrm{~g}$ of the extract was collected in a dry test tube and $5 \mathrm{ml}$ of chloroform was added and shake for 5 minutes, it was then be filtered and the filtrate will be shaken with an equal volume of $100 \%$ ammonia solution. A pink violet or red colour in the ammonia layer (lower layer) indicates the presence of free anthraquinone (igitate's test). The quantitative estimation was done according to Harbone (1973) method.

\subsection{Experimental Diets}

Five experimental diets were formulated and prepared for this experiment. Feed ingredients were used to $40 \%$ crude protein. In other diets, alligator pepper meal was included as additive in the following ratio $0 \%, 1.50 \%, 3.00 \%, 4.50 \%$ and $6.00 \%$ and coded of $\mathrm{T} 1, \mathrm{~T} 2, \mathrm{~T} 3, \mathrm{~T} 4$, and $\mathrm{T} 5$ respectively as presented in table 1 . The feed ingredients were fishmeal, soybean meal, groundnut cake, alligator pepper, maize, vitamin premix, salt and palm oil. The various ingredients were grinded to a fine powdered form and thoroughly mixed in a bowl to form a homogenous mixture. Premix and water were added followed by starch as a binding agent. Experimental feeds were pelletized using the mechanical pelletizer, then sundried, labeled and packaged in an air tight bag stored for use thereafter.

\subsection{Feeding and Monitoring}

The fish were staved 24 hours to empty their gastro-intestinal tracts before the commencing of the feeding trials (Eyo, 2004). The experimental fish were fed with 5\% of their body weight per day for 12 weeks. The fish in each tank was batch-weighed weekly throughout the feeding trial using sensitive weighing balance, to determine the feed adjustment based on weight gained. The fish were fed between 8-9am and 5-6pm daily. The fish were monitored for survival by removing the dead fish and recording their numbers. 
Effects of Alligator Pepper (Aframomum Melegueta) Meal Additive Diets on Haematological Indices of Clarias Gariepinus (Burchell, 1822)

\subsection{Water Quality Parameters}

The water quality parameters monitored throughout the experiment are temperature, $\mathrm{pH}$, Ammonia and Dissolved oxygen using Boyd (1990) method, being the most important water parameters.

Table1. Ingredient Gross Compositions (g/100) of Experimental Diets

\begin{tabular}{|c|c|c|c|c|c|}
\hline Ingredients & T1 & T2 & T3 & T4 & T5 \\
\hline Soybean & 20.00 & 20.00 & 20.00 & 20.00 & 20.00 \\
\hline Groundnut cake & 15.04 & 15.04 & 15.04 & 15.04 & 15.04 \\
\hline Fishmeal & 20.00 & 20.00 & 20.00 & 20.00 & 20.00 \\
\hline Maize & 39.30 & 36.80 & 34.30 & 31.80 & 29.30 \\
\hline Alligator pepper meal & 0.00 & 1.50 & 3.00 & 4.50 & 6.00 \\
\hline Oil & 2.00 & 2.00 & 2.00 & 2.00 & 2.00 \\
\hline Vitamin \& Mineral premixes & 0.25 & 0.25 & 0.25 & 0.25 & 0.25 \\
\hline Methionine & 0.50 & 0.50 & 0.50 & 0.50 & 0.50 \\
\hline Lysine & 0.50 & 0.50 & 0.50 & 0.50 & 0.50 \\
\hline Salt & 0.25 & 0.25 & 0.25 & 0.25 & 0.25 \\
\hline Starch & 3.00 & 3.00 & 3.00 & 3.00 & 3.00 \\
\hline Total & 100.00 & 100.00 & 100.00 & 100.00 & 100.00 \\
\hline
\end{tabular}

Keys: $T 1=0.00 \%$ of Alligator pepper; T2=1.50\% of Alligator pepper; $T 3=3.00 \%$ of Alligator pepper; T4=4.50\% of Alligator pepper, $T 5=6.00 \%$ of Alligator pepper

\subsection{Determination of Blood Parameters}

Blood analysis: 5-10 mL blood samples were collected from cardiac puncture using $2 \mathrm{~mL}$ disposable heparinised syringe treated with EDTA as anti-coagulant.

Blood cell count: Haemocytometer was used in blood cell count. The blood diluting fluid was prepared as described by Svobodova et al. (1991). The blood cells were counted on the counting chamber of haemocytometer with the aid of compound microscope:

Haemoglobin estimation: Haemoglobinometer was used for haemoglobin estimation based on acid haematin method (SAHLI):

$$
\text { Haemoglobin }=\frac{\text { Value obtained }}{100} \times 17.2 \mathrm{mg} / 100 \mathrm{~mL}
$$

Red Blood Cell $=$ No of cells counted x3x10x200 (106 mm3)

White Blood Cell $=$ No of cells counted x0x25x10x20 (104 mm3)

Packed cell volume: The packed cell volume was measured after placing sealed micro-haematocrit tube in a centrifuge at 10,500 rpm using micro-haematocrit reader and expressed as percentage.

Erythrocyte sedimentation rate (ESR): ESR was determined the procedures of Svobodova et al. (1991). The volume of ESR with the given time interval is the difference between $100 \%$ and the percentage part presented by the corpuscle volume.

Mean corpuscular volume (MCV): MCV was calculated from the haematocrit value (PCV, $\%$ and the Erythrocyte count (Er mm3):

$$
\operatorname{MCV}\left(\mu^{3}\right)=\frac{\mathrm{PCV}}{\mathrm{Er}} \times 10
$$

Mean corpuscular haemoglobin concentration (MCHC): This was obtained using the formula:

$$
\mathrm{MCHC}(\%)=\frac{\mathrm{Hb}}{\mathrm{PCV}} \times 100
$$

Mean corpuscular haemoglobin (MCH): This was expressed in picograms ( $\rho g)$ :

$$
\mathrm{MCH}(\mathrm{pg})=\frac{\mathrm{Hb}}{\mathrm{Er}} \times 10^{2}
$$


Effects of Alligator Pepper (Aframomum Melegueta) Meal Additive Diets on Haematological Indices of Clarias Gariepinus (Burchell, 1822)

\subsection{Statistical Analysis}

The Data on survival rate, weight gain, food conversion ratio and hematological parameter were analyzed statistically using one way analysis of variance (ANOVA) at 5\% probability and Means were separated using LSD. All analysis was done using Graphad Instat Window 10.

\section{RESUlts}

\subsection{Phytochemical Screening of the Alligator Pepper}

Table2. Information on the quantitative phytochemical present in Alligator pepper fruit. Seven phytochemicals including: Tannin, Saponin, Alkaloids, Flavonoids, phytate, steroids and anthraquinones. The lowest phytochemical result was from steroids, $0.35 \pm 0.01$ and highest from tannin, 4.835 \pm 0.015 . On Table3, the haematological profiles of Clarias garieinus fed different Alligator pepper meal Additive diets are presented. There were variations in the values of some of the parameters as the diet varies. There were significant differences $(\mathrm{p}<0.05)$ between all the indices as the diets varied

Table2. Quantitative Phytochemical Analysis of Alligator Pepper

\begin{tabular}{|c|c|}
\hline Phytochemical & Quantity (\%) \\
\hline Tannin & $4.835 \pm 0.015$ \\
\hline Saponin & $0.52 \pm 0.001$ \\
\hline Alkaloids & $3.45 \pm 0.01$ \\
\hline Flavonoids & $2.23 \pm 0.01$ \\
\hline Phytates & $1.72 \pm 0.01$ \\
\hline Steroids & $0.35 \pm 0.01$ \\
\hline Anthraquinones & $1.24 \pm 0.02$ \\
\hline
\end{tabular}

Table3. Some Heamatological and Biochemical indices of Clarias gariepinus fed Alligator pepper meal Additive diets

\begin{tabular}{|c|c|c|c|c|c|c|c|c|c|c|}
\hline Treatments & $\begin{array}{c}\mathbf{R B C} \\
\mathbf{C} / \mathbf{L}\end{array}$ & $\begin{array}{c}\mathbf{W B C} \\
\mathbf{C} / \mathbf{L}\end{array}$ & $\begin{array}{c}\mathbf{P C V} \\
\mathbf{g} / \mathbf{l}\end{array}$ & $\begin{array}{c}\mathbf{H b} \\
\mathbf{\%}\end{array}$ & $\begin{array}{c}\mathbf{B P} \\
\mathbf{\%}\end{array}$ & $\begin{array}{c}\mathbf{N E U} \\
\mathbf{g} / \mathbf{d l}\end{array}$ & $\begin{array}{c}\mathbf{M O N} \\
\mathbf{g} / \mathbf{d l}\end{array}$ & $\begin{array}{c}\mathbf{L Y M} \\
\mathbf{g} / \mathbf{d l}\end{array}$ & $\begin{array}{c}\text { BES } \\
\mathbf{g} / \mathbf{d l}\end{array}$ & $\begin{array}{c}\mathbf{E S I} \\
\mathbf{g} / \mathbf{d l}\end{array}$ \\
\hline $\mathrm{T} 1$ & $9.0 \pm 0.2^{\mathrm{a}}$ & $4000 \pm 102^{\mathrm{bc}}$ & $46 \pm 5^{\mathrm{a}}$ & $15.0 \pm 1.0^{\mathrm{a}}$ & $73 \pm 5^{\mathrm{a}}$ & $68 \pm 6^{\mathrm{a}}$ & $0 \pm 0^{\mathrm{b}}$ & $32 \pm 4^{\mathrm{c}}$ & $0 \pm 0$ & $0 \pm 0$ \\
\hline $\mathrm{T} 2$ & $5.8 \pm 0.1^{\mathrm{bc}}$ & $4800 \pm 110^{\mathrm{b}}$ & $38 \pm 4^{\mathrm{b}}$ & $12.6 \pm 1.2^{\mathrm{ab}}$ & $70 \pm 6^{\mathrm{a}}$ & $58 \pm 4^{\mathrm{b}}$ & $2 \pm 0.3^{\mathrm{a}}$ & $40 \pm 5^{\mathrm{a}}$ & $0 \pm 0$ & $0 \pm 0$ \\
\hline $\mathrm{T} 3$ & $4.9 \pm 0.3^{\mathrm{c}}$ & $5200 \pm 87^{\mathrm{b}}$ & $36 \pm 7^{\mathrm{b}}$ & $12.0 \pm 2.0^{\mathrm{ab}}$ & $68 \pm 4^{\mathrm{ab}}$ & $62 \pm 3^{\mathrm{b}}$ & $2 \pm 0.01^{\mathrm{a}}$ & $35 \pm 6^{\mathrm{bc}}$ & $0 \pm 0$ & $0 \pm 0$ \\
\hline $\mathrm{T} 4$ & $6.2 \pm 0.1^{\mathrm{b}}$ & $3600 \pm 98^{\mathrm{c}}$ & $42 \pm 9^{\mathrm{ab}}$ & $14.0 \pm 3.0^{\mathrm{a}}$ & $64 \pm 5^{\mathrm{b}}$ & $62 \pm 2^{\mathrm{ab}}$ & $1 \pm 0.0^{\mathrm{a}}$ & $38 \pm 4^{\mathrm{ab}}$ & $0 \pm 0$ & $1 \pm 0.1$ \\
\hline $\mathrm{T} 5$ & $3.6 \pm 0.2^{\mathrm{d}}$ & $6000 \pm 107^{\mathrm{a}}$ & $10 \pm 2^{\mathrm{d}}$ & $10 \pm 4^{\mathrm{b}}$ & $62 \pm 4^{\mathrm{b}}$ & $68 \pm 4^{\mathrm{a}}$ & $0 \pm 0^{\mathrm{b}}$ & $32 \pm 3^{\mathrm{c}}$ & $0 \pm 0$ & $0 \pm 0$ \\
\hline
\end{tabular}

Means on the same column with different superscripts are significantly different ( $p \leq 0.05)$

Keys:

$R B C=$ Red blood count;

$W B C=$ White blood count

PCV = Packed cell volume;

$H b=$ Hemoglobin concentration

$B P=$ Blood protein;

$N E U=$ Neutrophil

MON = Monocyte;

LYM =Lymphocyte

BES = Basophil;

ESI=Eosinophil

Table4. Correlation ( $r$ ) of the Some haematological parameters of Clarias gariepinus fed Alligator pepper meal additive diets

\begin{tabular}{|c|c|c|c|c|c|c|c|c|c|}
\hline & RBC & WBC & PCV & HB & BP & NEU & MON & LYM & ESI \\
\hline RBC & & & & & & & & & \\
\hline WBC & 0.206175 & & & & & & & & \\
\hline PCV & 0.149281 & -0.86902 & & & & & & & \\
\hline HB & -0.11696 & -0.94171 & 0.926993 & & & & & & \\
\hline BP & 0.158581 & -0.39064 & 0.718429 & 0.653805 & & & & & \\
\hline NEU & -0.19568 & 0.183543 & -0.37109 & -0.06482 & -0.11921 & & & & \\
\hline MON & 0.547794 & 0.00000 & 0.317564 & -0.05204 & 0.16855 & -0.92253 & & & \\
\hline LYM & -0.07126 & -0.33951 & 0.390552 & 0.165832 & 0.034548 & -0.95406 & 0.768648 & & \\
\hline ESI & -0.2473 & -0.65561 & 0.299817 & 0.372395 & -0.42714 & -0.20628 & 0.00000 & 0.40625 & \\
\hline
\end{tabular}

International Journal of Innovative Studies in Aquatic Biology and Fisheries 


\section{DISCUSSION}

According to the experimental result, it was found that Alligator pepper has the fallowing phytochemical tannin, saponin, alkaloid, flavonoid, phytates, steroid, and anthraquinones. Dreosti (2000) phyto-chemicals are biological compounds found in plants in small amounts, which are not established nutrients but contribute significantly to protection against degenerative diseases. Alligator pepper changed in its flavonoid content from $7.281 \%$ to $4.192 \%$. The lowest value of flavonoid $(0.066-0.183 \%)$ was discovered in kola nut. This result showed the effect of the drying temperature on the properties of phytochemicals examined. The tannin content of garlic was the highest at $38.45 \%$ and was reduced to $22.32 \%$ dry milled sample.

The tannin content of kola nut was reduced from 8.6425 to $5.444 \%$ after drying process, pepper fruit recorded the lowest tannin content and changed value from $1.321 \%$ to $0.224 \%$. Despite the change in the phytochemical composition as a result of drying processes, the quantity obtained is still biologically active. Dreosti (2000) stated that phytochemicals are biological compounds found in plants in small amounts, which are not established nutrients but contribute significantly to protection against degenerative diseases.

The phytate content was equally by drying process. The values obtained from raw samples reduced after drying. However, garlic recorded $2.461 \mathrm{mg} / 100 \mathrm{~g}$ which was later reduced to $1.181 \mathrm{mg} / 100 \mathrm{~g}$. Pepper fruit changed in its phytate content from $0.963 \mathrm{mg} / 100 \mathrm{~g}$ to $0.051 \mathrm{mg} / 100 \mathrm{~g}$ dry milled sample. The least phytate content was found in alligator pepper. The variation observed could be the effect from different chemical properties of the raw materials used. reduced after drying. However, garlic recorded $2.461 \mathrm{mg} / 100 \mathrm{~g}$ which was later reduced to $1.181 \mathrm{mg} / 100 \mathrm{~g}$. Pepper fruit changed in its phytate content from $0.963 \mathrm{mg} / 100 \mathrm{~g}$ to $0.051 \mathrm{mg} / 100 \mathrm{~g}$ dry milled sample. The least phytate content was found in alligator pepper. The variation observed could be the effect from different chemical properties of the raw materials used.

Alkaloid was found in kola nut, alligator pepper and pepper fruit only. The alkaloid content varied significantly $(\mathrm{p}<0.05)$, Kola nut had the highest value at $10.263 \%$ of raw sample, and was reduced to $8.20 \%$ after drying. The lowest value was recorded in alligator pepper $(0.028 \%)$ after drying process. Enemor et al. (2014) said that alkaloids are wide and varied in structure and function. Most alkaloids are physiologically and pharmacologically-functionally useful, some have deleterious effects and may cause growth depression in animals. Therefore, the decreased amount discovered as a result of drying process is an advantage nutritionally. Gas chromatography and gas chromatography-mass spectrometry have been used in characterizing 27 compounds, which constitute $98.6 \%$ of the essential oil (Ajaiyeoba and Ekundayo, 1999). These compounds include two sesquiterpene hydrocarbons, humelene and caryophyllene, which make up $82.6 \%$ of this volatile oil (Ajaiyeoba and Ekundayo, 1999). The oxides of humulene and caryophyllene constitute another $9 \%$ of the oil while 17 other mono and sesquiterpenes account for only one percent (Ajaiyeoba and Ekundayo, 1999).

Alligator pepper seeds are an excellent source of phytonutrients such as terpenoids, alkaloids, flavonoids, tannins, cardiac glycosides, saponin and phenolic compound. They scavenge for free radicals and offer protections against viruses, allergens, microbes, platelet aggregation, tumors, ulcers and hepatotoxins (chemical liver damage) in the body. This suggests why it is commonly used in folk medicine for preventing and tackling intestinal problems by Okigbo et al. (2009).

White blood cell counts are useful as indicators of disease condition or response to infection and significantly elevated or depressed values are obtained in abnormal conditions. Similarly, it is a function of the immunity and this makes fish resistance to some vulnerable disease. There is marked increase in the white blood cell count across the treatments compare with normal value $\left(6.6+10^{6} / \mathrm{u}\right)$ recommended by Adedeji et al. (2000). The WBC in this study is significant different and higher than the value $\left(7+10^{6} / \mathrm{mm} 3\right)$ obtained by Fagbenro et al., (1993).

Hematological results also showed the hematocrit which is important as an indicator of the percentage of packed red blood cells and the color of the plasma layer above the packed cells, and could be used to detect hemolysis (Acher and Jeffcott, 1977). There is therefore the possibility of using hematocrit as tool in Aquaculture and fisheries management for checking anemic condition in fishes. 
In fish blood, oxygen is carried in physical solution and also in combination with hemoglobin (Fagbenro et al., 2000). Hemoglobin is crucial for the survival of fish as its value rages between 10 and $15 \mathrm{~g} / \mathrm{dl}$. This is higher than the values $7.44-8.66 \mathrm{~g} / \mathrm{dl}$ reported for estuarine catfish, $C$. isheriensis, C. gareipinus, H. longifilis and H. bidorsalis (Kori-Siakpere, 1985; Fagbenro et al.,1993; Erondu et al.,1993).

The packed cell volume PCV values range from $(10-46 \mathrm{~g} / \mathrm{dl})$ were higher than the value $30-35 \mathrm{~g} / \mathrm{dl}$ recorded by Adedeji et al. (2000). Similarly, in this study there are wide variations in blood protein 62-73 recorded with the fish fed $\mathrm{T} 1 \mathrm{had}$ the highest values.

Blood analysis is a valuable means of evaluating the physiological condition of cultured fish with respect to determining the effect of diets and other stress factors on fish health. Changes in haematology of fish in response to stressing agents are indicators of the stressful stage of fish, producing useful information to curb any unfavourable condition that may affect the fish health (Bello-Olusoji et al., 2006). The analysis of blood is an important factors that could be considered in fish feed assessment (Adeparusi and Ajayi, 2004). The use of haematological values as indices of diagnosing diseases and stress induced condition as well as for feed assessment is well documented by Akintayo et al., 2008

Alligator Pepper as Additive Diets at 1.50, 3.00, 4.50 and 6.00 Alligator Pepper as Additive Diets increase the white blood cell which resulted to the high survival rate of the fingerlings.

\section{REFERENCES}

[1] Adedeji, O.B., Taiwo, V.O, and Agbede, S.A (2000). Comperative haematology of five Nigeria Freshwater fish species. Nigeria Veterinary Journal, 121:75-84

[2] Adeparusi, E. O. and A.D. Ajayi, (2004). Hematological characteristics of Nile Tilapia (Oreochromis niloticus) fed differently processed lima bean (Phaseolus lunatus L.) diets. Journal of Research Science Management, 2: 73-80.

[3] Ahmad, M. S, and Ahmed N. (2006). Antiglycation properties of aged garlic extract: possible role in prevention of diabetic complications. Journal of Nutrition. 136(suppl. 3):796s-799s.

[4] Ajaiyeoba, E. O. and Ekundayo, O. (1999). Essential oil constituents of Aframomum melegueta (roscoe) k. schum) seeds (alligator pepper) from Nigeria. Flavour and Fragrance Journal 14(2):109-111.

[5] Akintayo, I. A., S.O. Obasa, W.O. Alegbeleyo and A.N. Bangbose, (2008). Evaluation of toasted sunflower (Helianthus annus) seed meal in the diets of African catfish (Clarias gariepinus) fingerling. Livestock Research Rural Development, 20: 28-46.

[6] Akinwande, A.A., F.O. Moody, O.A. Sogbesan, A.A.A. Ugwumba and S.O. Ovie, (2004). Haematological response of Heterobranchus longifilis fed varying dietary protein levels. Proceedings of the 19th Annual Conference of the Fisheries Society of Nigeria, November 29-December 3, 2004, Ilorin, Nigeria, pp: 715718.

[7] Archer, R.K and Jeffcott, L.B.(1977).The haematological assessment of the health of freshwater fish. A review of selected literature. Journal of fish Biology,4: 593-604.

[8] Barros, M. M., Lim, E. and Klesius, P. H. (2002). Effect of soybean replacement by cottonseed meal and iron supplementation on growth, immune response and resistance of channel catfish (Ictalurus punctatus) to Edwarsiella ictaluri challenge. Aquaculture, 207: 263-279.

[9] Bello-Olusoji O.A., Omoare ,V. Y. and Nwana, L.C. (2006). Comparative Studies on the haematological characteristics of pond-cultured and wild tilapia (Oreochromis niloticus) (Linnaeus, 1857). Nigerian Journal of Forestry, 36: 134-141.

[10] Bingham, M., Chance M., and Widdowson H.L., (2001); Methods for Anti-Nutrients determination. Analytical. Chemistry., 43; 841-847

[11] Blom, J.H., Lee, K.J., Rinchard, J., Dabrowski, K. and Ottobre, J. (2001). Reproductive efficiency and maternal-offspring transfer of gossypol in rainbow trout (Oncorhynchus mykiss) fed diets containing cottonseed meal. Journal Animal Science., 79: 1533-1539.

[12] Boyd, C., (1990). Water Quality. In: Aquaculture: farming of Aquatic animals and plants. $2^{\text {nd }}$ edition. Eds. Lucas, J.S. \& Southgate, P.C. John Wiley \& Sons.

[13] Brunner, J.H. (1984). Direct spectrophotometer determination of saponin. Analytical Chemistry, 34:13141326. 
[14] Dabrowski, K., Lee, K.J., Rinchard, J., Ciereszko, A., Blom, J.H. and Ottobre, J.S. (2001). Gossypol Isomers bind specifically to blood plasma proteins and spermatozoa of rainbow trout fed diets containing cottonseed meal. Biochimica Biophysica Acta (BBA)-Gen. Subj., 1525: 37-42.

[15] Dreosti, C.I. (2000). Biological components in plants and their usefulness. Washington D.C. pp 9-10.

[16] El-Saidy, D.M.S.. and Gaber, M.M. (2004). Use of cottonseed meal supplemented with iron for detoxification of gossypol as a total replacement of fish meal in Nile tilapia, (Oreochromis niloticus) (L.) diets. Aquaculture of Research, 35: 859-865.

[17] Enemor, Modie J.A and Ennison, B. (2014). Biological compounds and Their functions. Journal of pharmacy 8: 78-90.

[18] Eyo, A.A. ( 2004). Fundamentals of fish nutrition and diet development an overview.Pp.1-33.In A A.Eyo (ed). National workshop on fish feed development and feeding practices in aquaculture NIFFRI,Newbussa $15^{\text {th }}$ to $19^{\text {th }}$ September,2003.65pp.

[19] Erondu, E.S., Nnubia, C. and Nwadukwe, F.O. 1993. Haematological studies of four catfish species raised in freshwater ponds in Nigeria. Journal of Applied Ichthyology9:250-256.

[20] Ezeric, G.N.O. (2001). Haemotological responses of Clarias gariepinus to bacterial infection and prophylactic treatment with antibiotics. Journal of Aquatic Science 2 (16):22-24.

[21] Fagbenro, O. A., Adedire,C.O., Oweseeni, E.A. and Faminu, E.O.(1993). Studies on the biology and Aquacultural potential of feral catfish, Heterobranchus bidorsalis (Geoffrey St.Hilaire 1809).Tropical Zoology; 13:1-9.

[22] Fagbenro, O.A., Adedire.,C.O. Ayotunde,E.0.and Faminu, E.O.(2000) .Haemotological profile, food composition and digestive enzymes assay in the gut of Africa bony tongue fish,Heterotis niloticus (Cuvier,1826) (Osteoglossidae).Tropical Zoology;13:1-9.

[23] Gabriel, U. U., Akinrotimi, O. A., Bekibebe, D. O. and Anyanwu, P. E. (2007). Locally produced fish feed: Potentials for aquaculture development in sub-Saharan Africa. Africa Journal of Agriculture Research, 2(2):287-295

[24] Gabriel, U.U., Ezeri, G.N.O. and Opabunmi, O.O. (2004). Influence of sex, source, health status and acclimation on the haemotology of (Burchell, 1822). African Journal of Biotechnology, 3(9):463-487

[25] Harborne, J. B., (1973). Phytochemistry. Academic Press, London, Pp. 89-131.

[26] Hecht, T.I., Oeilerman, L. and Verheust, L.(1996). Perspective on Clariid catfish culture in Africa. Aquatic Living Resource, 9: 197-206.

[27] Hossanin, M.A., Nahar, N.,Kamal, Islam, M.N.(1995).Nutrient digestibility coefficients of some plants and animal proteins for tilapia (Oreochromis mossambicus).Journal Aquaculture in the Tropics, 7;257-266.

[28] Hrubec, T. C., Cardinale, J.L., Smith, S.A. (2000). Hematology and plasma chemistry reference intervals for cultured tilapia (oreochromis hybrid). Veterinary Clinical pathology, 29(1): 7-12.

[29] Kori-Siakpere. O. (1985). Hematological characteristics of Clarias isheriensis Sydeham .Journal of fish Biology,27: 259-263.

[30] Mshelia G. D., Amin JD and Chaudhari SUR (2000). Oestrus detection in the Nigerian Mongrel bitch: Application of vaginal cytology. Pakistan veterinary Journal 21(1):44-46.

[31] Okigbo, R.N., Ramesh, P., and Achusi, C.T. (2009). Post-Harvest Deterioration of Cassava and its Control using extracts of Azadirachta indica and Aframomum melegueta. E-Journal of Chemistry. 6(4):1274-1280.

[32] Osuigwe, D.I.,Obejezie, A.I. and Onuoha,G.I. (2007). Some haemotological changes in hybrid catfish (Heterobranchus longifilis x Clarias gariepinus) fed different dietary levels of raw and boiled jackbean (Canavalia ensiformis) seed meal. African Journal of Biotechnology, 8(4): 1017-1021.

[33] Rainzapaiva, M. J. Ishikawa, C. M., Das-Eiras, A. A. and Felizardo, N. N. (2000). Haematological Analysis of Chara (Pesudoplatystoma fasciatum) in captivity. Proceeding of the International Conference on Responsible Aquaculture in the New Millennium, May 2-6, 2000,Nice, France,:590pp.

[34] Richard, J., Lee, K. J. Czesny, S., Ciereszko, A. and Dabrowski, K. (2003). Effect of feeding cottonseed meal contaning diets to broodstock rainbow trout and their impact on the growth of their progenies. Aquaculture, 227: 77-87.

[35] Sogbesan, O.A. and Ahmed, M.Y. (2018). Haematological Response of Clarias gariepinus Fed Ocimum gratissimum Additive Diets. EC. Nutrition 13(8):572-581

[36] Spinelli, J. (2007). Evaluating Alternative Protein Source in Aquaculture Diet. National Marine Fisheries, Services, Seattle, Washington.

[37] Svobodova, Z., Pravda, D. and Palackova, J. (1991). Unified Methods of Haematological Examination of Fish. Research Institute of Fish Culture and Hydrobiology, Vodnany, Czech Republic, Pages: 31. 
Effects of Alligator Pepper (Aframomum Melegueta) Meal Additive Diets on Haematological Indices of Clarias Gariepinus (Burchell, 1822)

[38] Swain, T. (1979). Tannins and lignin in herbivores: their interaction with Plant metabolites, Rosenthal G.A (Eds). Academic press, New York.

[39] Wedemeyer, G.A. and Yasutake, W.T. (1977). Clinical Methods for the Assessment of the Effects of Environmental Stress on Fish Health. Department of the Interior, Fish and Wildlife Service, USA., Pages: 18.

[40] Yue, Y. R. and Zhou, Q. C. (2008). Effect of replacing soybean meal with cotton seed meal on growth, feed utilisation and haematological indexes for juvenile hybrid tilapia (Oreochromis niloticus x O. aureus). Aquaculture, 284: 185-189.

Citation: Sogbesan, O.A, Kwankwa, T, "Effects of Alligator Pepper (Aframomum Melegueta) Meal Additive Diets on Haematological Indices of Clarias Gariepinus (Burchell, 1822)”, International Journal of Innovative Studies in Aquatic Biology and Fisheries, 6(3), pp. 7-15. DOI: https:// doi.org/10.20431/2454-7670.0603002

Copyright: (C) 2020 Authors, This is an open-access article distributed under the terms of the Creative Commons Attribution License, which permits unrestricted use, distribution, and reproduction in any medium, provided the original author and source are credited. 